\title{
Camalexin-Induced Cell Membrane Scrambling and Cell Shrinkage in Human Erythrocytes
}

\author{
Mustafa Almasry ${ }^{a}$ Mohamed Jemaàa $\quad$ Morena Mischitellia Caterina Faggiob \\ Florian Lang ${ }^{\mathrm{a}, \mathrm{c}}$ \\ ${ }^{a}$ Department of Internal Medicine III, Eberhard-Karls-University of Tuebingen, Tuebingen, Germany; \\ ${ }^{b}$ Department of Chemical, Biological, Pharmaceutical and Environmental Sciences-University of Messina \\ Viale Ferdinando Stagno d'Alcontres, S. Agata-Messina, Italy; 'Department of Molecular Medicine II, \\ Medical Faculty, Heinrich Heine University, Duesseldorf, Germany
}

\section{Key Words}

Phosphatidylserine $\bullet$ Cell volume $\bullet$ Eryptosis $\bullet$ Calcium $\bullet$ Staurosporine $\bullet$ Chelerythrine $\bullet$ zVAD

\begin{abstract}
Background/Aims: The thaliana phytoalexin Camalexin has been proposed for the treatment of malignancy. Camalexin counteracts tumor growth in part by stimulation of suicidal death or apoptosis of tumor cells. Similar to apoptosis of nucleated cells, erythrocytes may enter suicidal death or eryptosis, which is characterized by cell shrinkage and cell membrane scrambling with phosphatidylserine translocation to the erythrocyte surface. Cellular mechanisms contributing to the complex machinery executing eryptosis include increase of cytosolic $\mathrm{Ca}^{2+}$ activity $\left(\left[\mathrm{Ca}^{2+}\right]_{\mathrm{i}}\right)$, oxidative stress, ceramide, protein kinase $\mathrm{C}$ and caspases. The present study explored, whether Camalexin induces eryptosis and, if so, to shed light on mechanisms involved. Methods: Phosphatidylserine exposure at the cell surface was estimated from annexin-V-binding, cell volume from forward scatter, $\left[\mathrm{Ca}^{2+}\right]_{i}$ from Fluo-3 fluorescence, ROS formation from DCFDA dependent fluorescence, and ceramide abundance utilizing specific antibodies. Results: A 48 hours exposure of human erythrocytes to Camalexin significantly increased the percentage of annexin-V-binding cells ( $\geq 10 \mu \mathrm{g} / \mathrm{ml}$ ), significantly decreased forward scatter $(\geq 5 \mu \mathrm{g} / \mathrm{ml})$ and significantly increased Fluo-3-fluorescence $(\geq 10 \mu \mathrm{g} / \mathrm{ml})$, but did not significantly modify DCFDA fluorescence or ceramide abundance. The effect of Camalexin on annexin-V-binding was significantly blunted by removal of extracellular $\mathrm{Ca}^{2+}$, by kinase inhibitors staurosporine $(1 \mu \mathrm{M})$ and chelerythrine $(10 \mu \mathrm{M})$, as well as by caspase inhibitors zVAD $(10 \mu \mathrm{M})$ and ZIETDfmk $(50 \mu \mathrm{M})$. Conclusions: Camalexin triggers cell shrinkage and phospholipid scrambling of the erythrocyte cell membrane, an effect at least in part depending on $\mathrm{Ca}^{2+}$ entry, as well as staurosporine and chelerythrine sensitive kinase(s) as well as zVAD and zIETD-fmk sensitive caspase(s).
\end{abstract}




\section{Introduction}

The thaliana phytoalexin and indole alkaloid camalexin (3-thiazol-2'-yl-indole) [1-4] participates in the defense of plants against pathogens $[2,5-8]$. Moreover, the substance is effective against cancer cells $[2,9]$. Camalexin counteracts malignancy at least in part by triggering of cancer cell apoptosis [10-13].

In analogy to apoptosis of nucleated cells, erythrocytes may enter eryptosis, the suicidal death of erythrocytes [14]. Hallmarks of eryptosis are cell shrinkage [15] and cell membrane scrambling with phosphatidylserine translocation to the cell surface [14], events in common with apoptosis of nucleated cells. Erythrocytes lack, however nuclei and mitochondria, key organelles of apoptosis. Nevertheless apoptosis and eryptosis have a wide variety of triggers and signalling pathways in common [14]. Signaling involved in the triggering of eryptosis include increase of cytosolic $\mathrm{Ca}^{2+}$ activity $\left(\left[\mathrm{Ca}^{2+}\right]_{\mathrm{i}}\right)[14]$, ceramide [16], and oxidative stress [14]. Some stimulators of eryptosis are effective by activation of caspases $[14,17,18]$. Triggering of eryptosis may further involve stimulation of kinases [14]. Eryptosis is triggered by multiple xenobiotics [14, 19-65]. Moreover, enhanced eryptosis is observed in several clinical conditions including dehydration [14], hyperphosphatemia [14], chronic kidney disease (CKD) [66, 67], hemolytic-uremic syndrome [14], diabetes [68], hepatic failure [69], malignancy [14], sepsis [70], sickle-cell disease [14], beta-thalassemia [14], Hb-C and G6PDdeficiency [14], as well as Wilson's disease [71].

The present study explored, whether Camalexin modifies eryptosis. To this end, human erythrocytes from healthy volunteers were exposed to Camalexin and phosphatidylserine surface abundance, cell volume, $\left[\mathrm{Ca}^{2+}\right]_{\mathrm{i}}$, ROS formation, and ceramide abundance determined by flow cytometry.

\section{Materials and Methods}

\section{Erythrocytes, solutions and chemicals}

Fresh Li-Heparin-anticoagulated blood samples were kindly provided by the blood bank of the University of Tübingen. The study is approved by the ethics committee of the University of Tübingen $(184 / 2003 \mathrm{~V})$. The blood was centrifuged at $120 \mathrm{~g}$ for $20 \mathrm{~min}$ at $21^{\circ} \mathrm{C}$ and the platelets and leukocytescontaining supernatant was disposed. Erythrocytes were incubated in vitro at a hematocrit of $0.4 \%$ in Ringer solution containing (in mM) $125 \mathrm{NaCl}, 5 \mathrm{KCl}, 1 \mathrm{MgSO}_{4}, 32 \mathrm{~N}$-2-hydroxyethylpiperazine-N-2-ethanesulfonic acid (HEPES; pH 7.4), 5 glucose, $1 \mathrm{CaCl}_{2}$, at $37^{\circ} \mathrm{C}$ for 48 hours. Where indicated, erythrocytes were exposed for 48 hours to 5, 10, 15 and $20 \mu \mathrm{g} / \mathrm{ml}$ Camalexin (MedChem Express, Princeton, USA). Given the molecular weight of Camalexin $(200 \mathrm{~g} / \mathrm{mol}), 5 \mu \mathrm{g} / \mathrm{ml}$ corresponds to $25 \mu \mathrm{M}$. In order to estimate the impact of $\mathrm{Ca}^{2+}$ entry, erythrocytes were exposed to Camalexin in the absence of extracellular $\mathrm{Ca}^{2+}$ and presence of $\mathrm{Ca}^{2+}$ chelator EGTA (1 mM, Merck Millipore, Darmstadt, Germany). To test for an involvement of kinases, erythrocytes were exposed for 48 hours to a combination of Camalexin and protein kinase $\mathrm{C}$ inhibitor staurosporine (Sigma Aldrich, Hamburg, Germany), or p38 kinase inhibitor SB 203580 (Tocris bioscience, Bristol, UK), or casein kinase inhibitor D4476 (Sigma Aldrich, Hamburg, Germany). In order to test for a role of caspases, erythrocytes were exposed for 48 hours to a combination of Camalexin and pan-caspase inhibitor zVAD (Tocris bioscience, Bristol, UK),

\section{Annexin-V-binding and forward scatter}

After incubation under the respective experimental condition, a $150 \mu \mathrm{l}$ cell suspension was washed in Ringer solution containing $5 \mathrm{mM} \mathrm{CaCl}_{2}$ and then stained with Annexin-V-FITC (1:200 dilution; ImmunoTools, Friesoythe, Germany) in this solution at $37^{\circ} \mathrm{C}$ for 15 min under protection from light. The high $\mathrm{CaCl}_{2}$ concentration is required for the binding of annexin- $\mathrm{V}$ to phosphatidylserine. The annexin- $\mathrm{V}$-abundance at the erythrocyte surface was subsequently determined on a FACS Calibur (BD, Heidelberg, Germany). Annexin-V-binding was measured with an excitation wavelength of $488 \mathrm{~nm}$ and an emission wavelength of $530 \mathrm{~nm}$. A marker (M1) was placed to set an arbitrary threshold between annexin-V-binding cells and control cells. The same threshold was used for untreated and Camalexin treated erythrocytes. A dot plot 


\section{Cellular Physiology Cell Physiol Biochem 2017;41:731-741

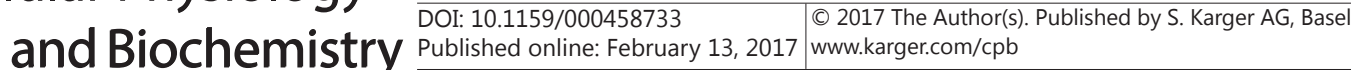

Almasry et al.: Camalexin-Induced Eryptosis

of forward scatter (FSC) vs. side scatter (SSC) was set to linear scale for both parameters. The threshold of forward scatter was set at the default value of " 52 ".

Intracellular $\mathrm{Ca}^{2+}$

After incubation, erythrocytes were washed in Ringer solution and loaded with Fluo-3/AM (Biotium, Hayward, USA) in Ringer solution containing $5 \mathrm{mM} \mathrm{CaCl}_{2}$ and $5 \mu \mathrm{M}$ Fluo-3/AM. The cells were incubated at $37^{\circ} \mathrm{C}$ for $30 \mathrm{~min} . \mathrm{Ca}^{2+}$-dependent fluorescence intensity was measured with an excitation wavelength of 488 $\mathrm{nm}$ and an emission wavelength of $530 \mathrm{~nm}$ on a FACS Calibur.

Reactive oxidant species (ROS)

Oxidative stress was determined utilizing 2', 7'-dichlorodihydrofluorescein diacetate (DCFDA). After incubation, a $150 \mu$ l suspension of erythrocytes was washed in Ringer solution and stained with DCFDA (Sigma, Schnelldorf, Germany) in Ringer solution containing DCFDA at a final concentration of $10 \mu \mathrm{M}$. Erythrocytes were incubated at $37^{\circ} \mathrm{C}$ for $30 \mathrm{~min}$ in the dark and washed two times in Ringer solution. The DCFDA-loaded erythrocytes were resuspended in $200 \mu$ l Ringer solution and ROS-dependent fluorescence intensity was measured at an excitation wavelength of $488 \mathrm{~nm}$ and an emission wavelength of $530 \mathrm{~nm}$ on a FACS Calibur (BD).

\section{Ceramide abundance}

For the determination of ceramide, a monoclonal antibody-based assay was used. To this end, cells were stained for 1 hour at $37^{\circ} \mathrm{C}$ with $1 \mu \mathrm{g} / \mathrm{ml}$ anti-ceramide antibody (clone MID 15B4, Alexis, Grünberg, Germany) in PBS containing 0.1\% bovine serum albumin (BSA) at a dilution of 1:10. The samples were washed twice with PBS-BSA. The cells were stained for 30 minutes with polyclonal fluorescein isothiocyanate (FITC) conjugated goat anti-mouse IgG and IgM specific antibody (Pharmingen, Hamburg, Germany) diluted 1:50 in PBS-BSA. Unbound secondary antibody was removed by repeated washing with PBS-BSA. The samples were analyzed by flow cytometric analysis with an excitation wavelength of $488 \mathrm{~nm}$ and an emission wavelength of $530 \mathrm{~nm}$. As a control, secondary antibody alone was used.

\section{Hemolysis}

Following incubation, the erythrocyte suspension was centrifuged for $3 \mathrm{~min}$ at $1600 \mathrm{rpm}, 4^{\circ} \mathrm{C}$, and the supernatant harvested. As a measure of hemolysis, the hemoglobin $(\mathrm{Hb})$ concentration in the supernatant was determined photometrically at $405 \mathrm{~nm}$. The absorption of the supernatant of erythrocytes lysed in distilled water was defined as $100 \%$ hemolysis.

\section{Statistics}

Data are expressed as arithmetic means \pm SEM. As indicated in the figure legends, statistical analysis was made using ANOVA with Tukey's test as post-test and $t$ test as appropriate. $\mathrm{n}$ denotes the number of different erythrocyte specimens studied. Since different erythrocyte specimens used in distinct experiments are differently susceptible to triggers of eryptosis, the same erythrocyte specimens have been used for control and experimental conditions.

\section{Results}

The present study explored whether Camalexin stimulates eryptosis, the suicidal erythrocyte death characterized by cell shrinkage and phospholipid scrambling of the cell membrane with phosphatidylserine translocation to the cell surface.

Erythrocyte volume was estimated from forward scatter which was determined utilizing flow cytometry. Prior to measurements, the erythrocytes were incubated for 48 hours in Ringer solution without or with Camalexin $(5,10,15$ and $20 \mu \mathrm{g} / \mathrm{ml})$. As illustrated in Fig. 1, Camalexin decreased erythrocyte forward scatter, an effect reaching statistical significance at $5 \mu \mathrm{g} / \mathrm{ml}$ Camalexin concentration.

Phosphatidylserine exposing erythrocytes were identified utilizing annexin-V-binding, as determined by flow cytometry. Prior to measurements, the erythrocytes were again 


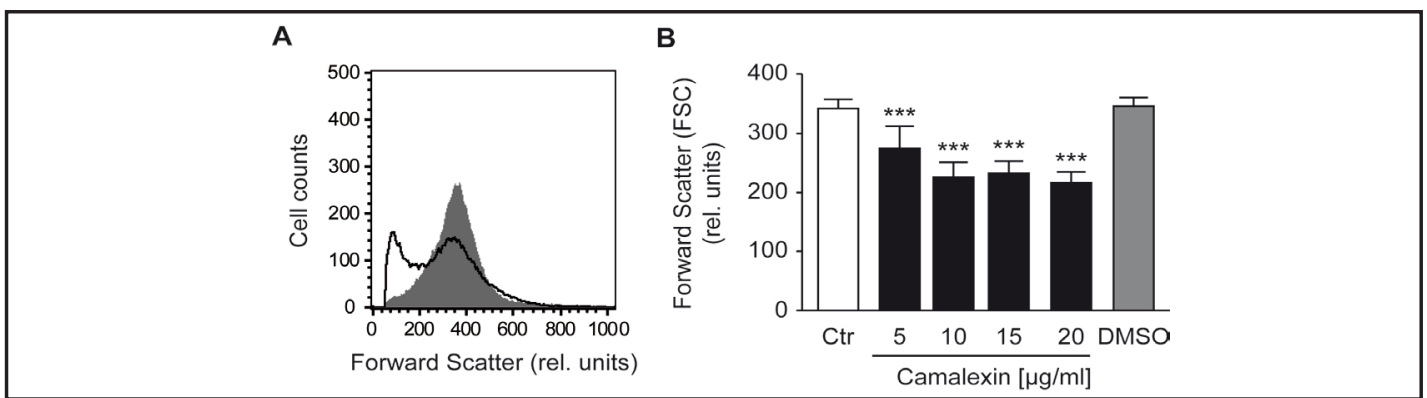

Fig. 1. Effect of Camalexin on erythrocyte forward scatter. A. Original histogram of forward scatter of erythrocytes following exposure for 48 hours to Ringer solution without (grey area) and with (black line) presence of $20 \mu \mathrm{g} / \mathrm{ml}$ Camalexin. B. Arithmetic means \pm SEM $(\mathrm{n}=12)$ of the erythrocyte forward scatter (FSC) following incubation for 48 hours to Ringer solution without (white bar) or with (black bars) Camalexin $(5,10,15$ and $20 \mu \mathrm{g} / \mathrm{ml})$. For comparison, the effect of the solvent DMSO is shown (grey bar). ${ }^{* * *}(\mathrm{p}<0.001)$ indicates significant difference from the absence of Camalexin (ANOVA).

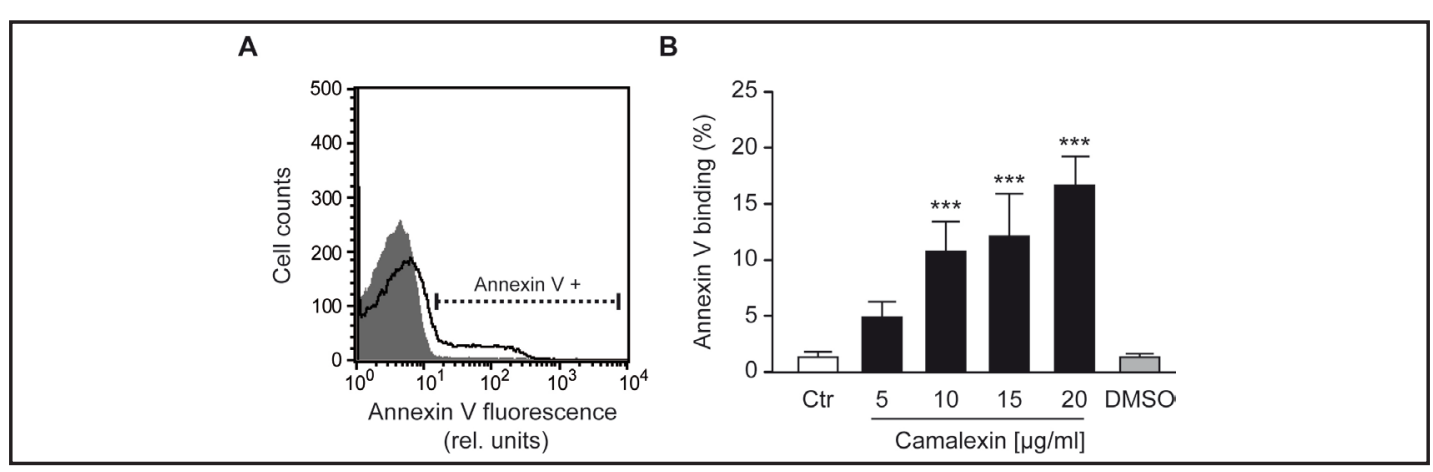

Fig. 2. Effect of Camalexin on phosphatidylserine exposure. A. Original histogram of annexin-V-binding of erythrocytes following exposure for 48 hours to Ringer solution without (grey area) and with (black line) presence of $20 \mu \mathrm{g} / \mathrm{ml}$ Camalexin. B. Arithmetic means \pm SEM ( $\mathrm{n}=12$ ) of erythrocyte annexin-V-binding following incubation for 48 hours to Ringer solution without (white bar) or with (black bars) Camalexin $(5,10,15$ and $20 \mu \mathrm{g} / \mathrm{ml})$. For comparison, the effect of the solvent DMSO is shown (grey bar). ${ }^{* * *}(\mathrm{p}<0.001)$ indicates significant difference from the absence of Camalexin (ANOVA).

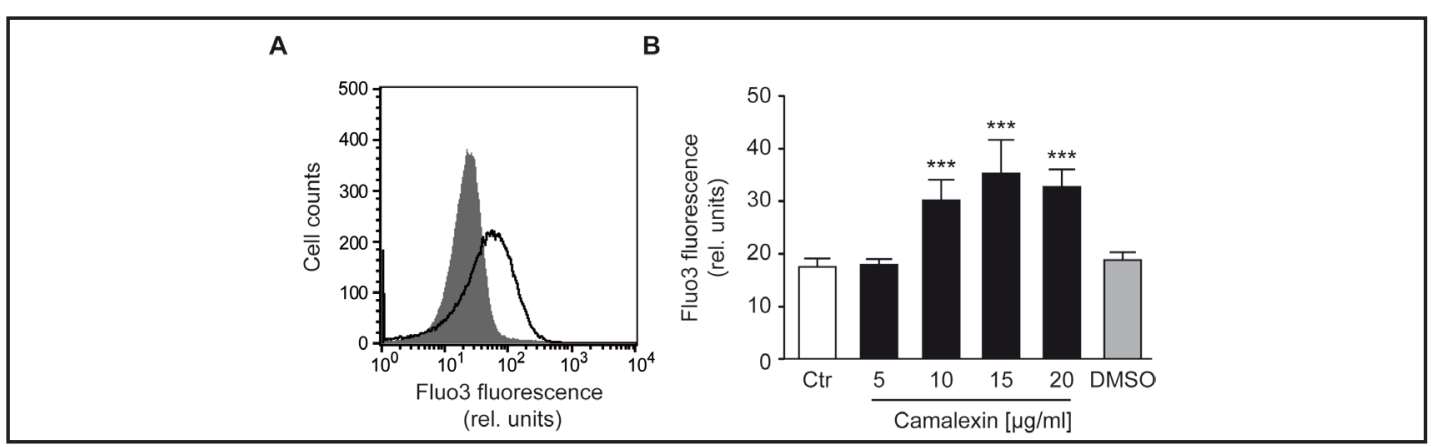

Fig. 3. Effect of Camalexin on cytosolic $\mathrm{Ca}^{2+}$ concentration. A. Original histogram of Fluo-3 fluorescence reflecting cytosolic $\mathrm{Ca}^{2+}$ concentration in erythrocytes following exposure for 48 hours to Ringer solution without (grey area) and with (black line) presence of $20 \mu \mathrm{g} / \mathrm{ml}$ Camalexin. B. Arithmetic means \pm SEM (n $=10$ ) of Fluo-3 fluorescence in erythrocytes following incubation for 48 hours to Ringer solution without (white bar) or with (black bars) Camalexin (5, 10, 15 and $20 \mu \mathrm{g} / \mathrm{ml}$ ). For comparison, the effect of the solvent DMSO is shown (grey bar). ${ }^{* * *}(\mathrm{p}<0.001)$ indicates significant difference from the absence of Camalexin (ANOVA).

incubated for 48 hours in Ringer solution without or with Camalexin (5, 10, 15 and 20 $\mu \mathrm{g} / \mathrm{ml}$ ). As shown in Fig. 2, a 48 hours exposure to Camalexin increased the percentage of 
Fig. 4. $\mathrm{Ca}^{2+}$ sensitivity of Camalexin -induced phosphatidylserine exposure. A,B. Original histograms of annexin-V-binding of erythrocytes following exposure for 48 hours to Ringer solution without (grey areas) and with (black lines) Camalexin $(20 \mu \mathrm{g} / \mathrm{ml})$ in the presence (A) and absence (B) of extracellular $\mathrm{Ca}^{2+}$. C. Arithmetic means \pm SEM $(n=10)$ of annexin-V-binding of erythrocytes after a 48 hours treatment with Ringer solution without (white bars) or with (black bars) Camalexin $(20 \mu \mathrm{g} / \mathrm{ml})$ in the presence (left bars, $+\mathrm{Ca}^{2+}$ ) and absence (right bars, $\left.-\mathrm{Ca}^{2+}\right)$ of $\mathrm{Ca}^{2+} . * * *(\mathrm{p}<0.001)$ indicates significant difference from the absence of Camalexin, \#\#\#(p<0.001) indicates significant difference from the presence of $\mathrm{Ca}^{2+}$ (ANOVA).
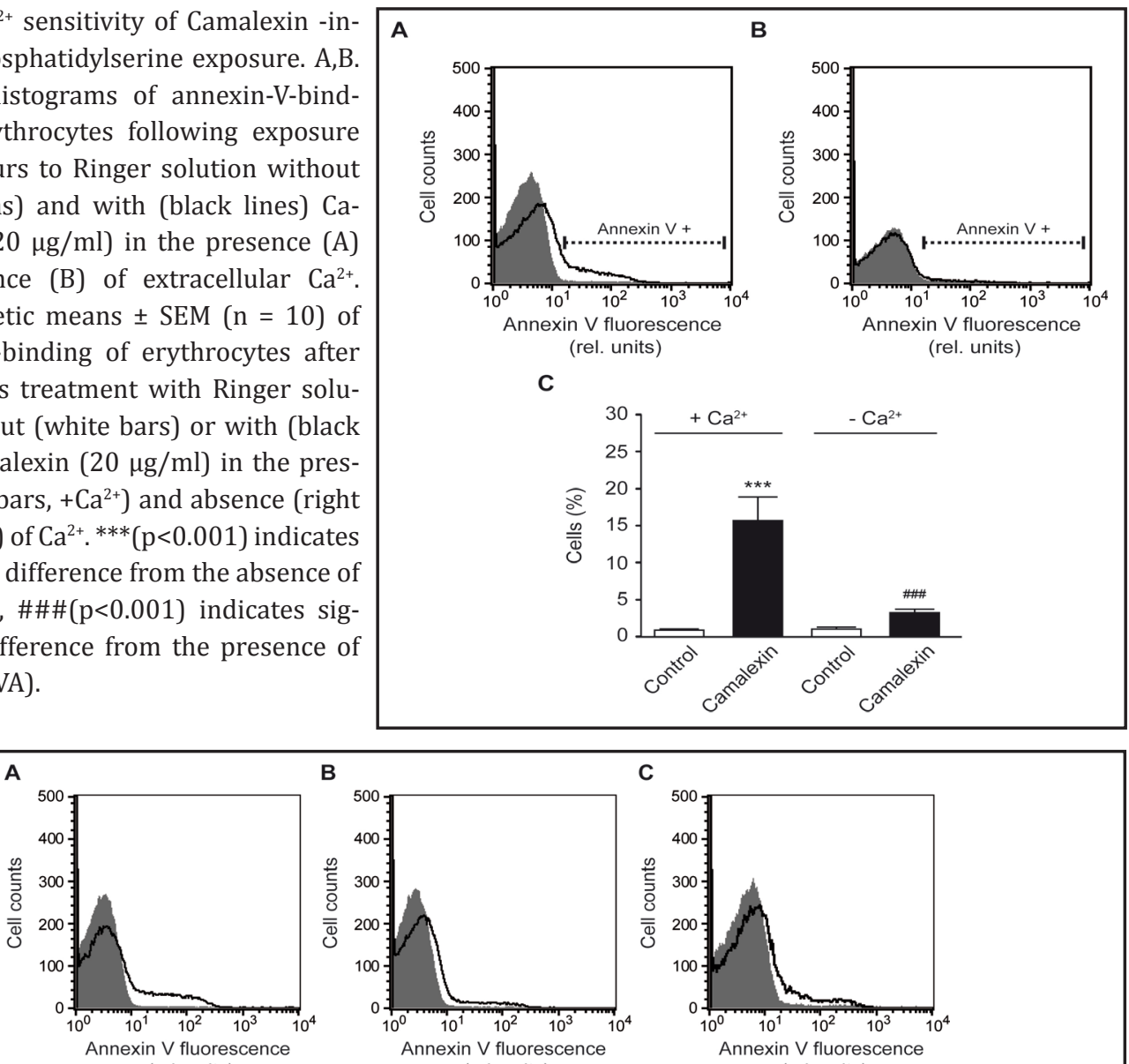

(rel. units)

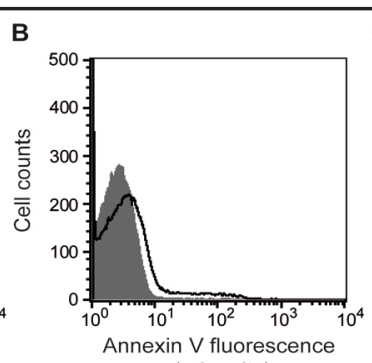

(rel. units)

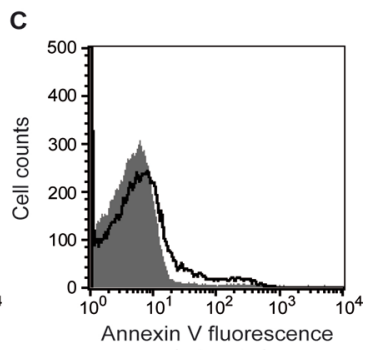

(rel. units)

D

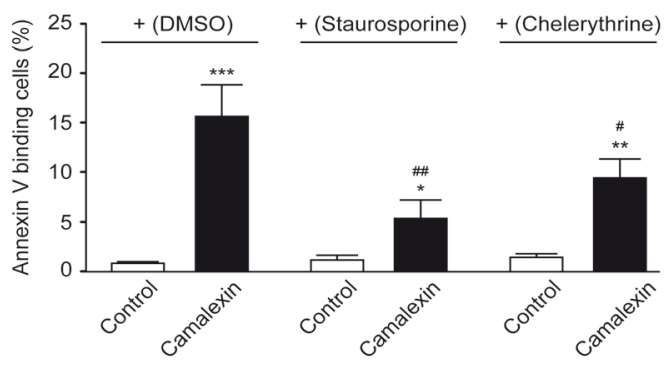

Fig. 5. Staurosporine and chelerythrine sensitivity of Camalexin -induced phosphatidylserine exposure. A,B. Original histograms of annexin-V-binding of erythrocytes following exposure for 48 hours to Ringer solution without (grey areas) and with (black lines) Camalexin $(20 \mu \mathrm{g} / \mathrm{ml})$ in the absence (A) and presence of (B) $1 \mu \mathrm{M}$ staurosporine or (C) $10 \mu \mathrm{M}$ chelerythrine. Arithmetic means \pm SEM $(n=8)$ of annexin-V-binding of erythrocytes after a 48 hours treatment with Ringer solution without (white bars) or with (black bars) Camalexin $(20 \mu \mathrm{g} / \mathrm{ml})$ in the absence (left bars, + DMSO) and presence of $1 \mu \mathrm{M}$ staurosporine (middle bars, + Staurosporine), or of $10 \mu \mathrm{M}$ chelerythrine (right bars, + chelerythrine). ${ }^{*}(\mathrm{p}<0.05),{ }^{* *}(\mathrm{p}<0.01),{ }^{* * *}(\mathrm{p}<0.001)$ indicates significant difference from the absence of Camalexin, $\#(p<0.05), \# \#(p<0.01)$ indicates significant difference from the absence of kinase inhibitors (ANOVA).

phosphatidylserine exposing erythrocytes, an effect reaching statistical significance at 10 $\mu \mathrm{g} / \mathrm{ml}$ Camalexin.

In order to test whether Camalexin triggers hemolysis, hemoglobin was determined in the supernatant. As a result, the percentage of hemolytic cells was similar following exposure 


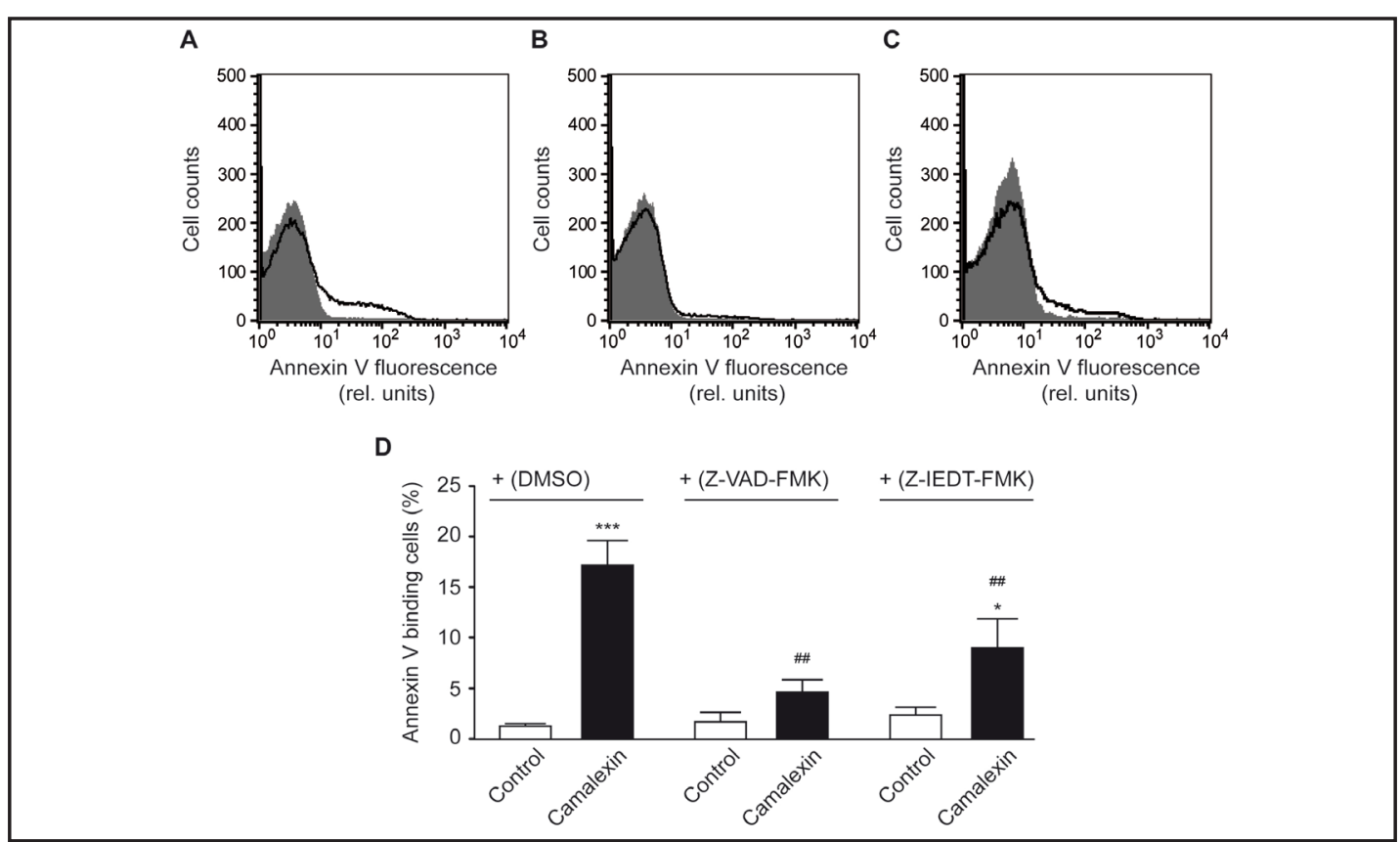

Fig. 6. zVAD sensitivity of Camalexin -induced phosphatidylserine exposure. A,B. Original histograms of annexin-V-binding of erythrocytes following exposure for 48 hours to Ringer solution without (grey areas) and with (black lines) Camalexin $(20 \mu \mathrm{g} / \mathrm{ml})$ in the (A) absence and presence of (B) $10 \mu \mathrm{M}$ pan-caspase inhibitor zVAD or of (C) $50 \mu \mathrm{M}$ caspase 8 inhibitor zIETD-fmk. Arithmetic means \pm SEM ( $n=10)$ of annexinV-binding of erythrocytes after a 48 hours treatment with Ringer solution without (white bars) or with (black bars) Camalexin $(20 \mu \mathrm{g} / \mathrm{ml})$ in the absence (left bars, DMSO) and presence of $10 \mu \mathrm{M} \mathrm{zVAD}$ (middle bars, + zVAD) or of $50 \mu$ M zIETD-fmk (right bars, + zIETD-fmk). ${ }^{*}(\mathrm{p}<0.05),{ }^{* * *}(\mathrm{p}<0.001)$ indicates significant difference from the absence of Camalexin, \#\#(p<0.01) indicates significant difference from the absence of caspase inhibitors (ANOVA).

to $20 \mu \mathrm{g} / \mathrm{ml}$ Camalexin $(5.1 \pm 0.8 \%, \mathrm{n}=4)$ and in the absence of Camalexin $(3.5 \pm 0.8 \%, \mathrm{n}=$ 4). Thus, Camalexin did not significantly increase hemolysis.

Fluo3 fluorescence was taken as a measure of cytosolic $\mathrm{Ca}^{2+}$ activity $\left(\left[\mathrm{Ca}^{2+}\right]_{\mathrm{i}}\right)$. Prior to measurements, the erythrocytes were again incubated for 48 hours in Ringer solution without or with Camalexin (5, 10, 15 and $20 \mu \mathrm{g} / \mathrm{ml})$. As shown in Fig. 3, a 48 hours exposure to Camalexin increased the Fluo-3 fluorescence, an effect reaching statistical significance at $10 \mu \mathrm{g} / \mathrm{ml}$ Camalexin.

A next series of experiments explored whether the Camalexin-induced translocation of phosphatidylserine or erythrocyte shrinkage required entry of extracellular $\mathrm{Ca}^{2+}$. To this end, erythrocytes were incubated for 48 hours in the absence or presence of $20 \mu \mathrm{g} / \mathrm{ml}$ Camalexin in the presence or nominal absence of extracellular $\mathrm{Ca}^{2+}$. As illustrated in Fig. 4, removal of extracellular $\mathrm{Ca}^{2+}$ significantly blunted the effect of Camalexin on the percentage of annexinV-binding erythrocytes. Thus, Camalexin-induced cell membrane scrambling was at least in part triggered by entry of extracellular $\mathrm{Ca}^{2+}$.

Eryptosis is further stimulated by oxidative stress. Reactive oxygen species (ROS) was thus quantified utilizing $2^{\prime}, 7^{\prime}$-dichlorodihydrofluorescein diacetate (DCFDA). As a result, the DCFDA fluorescence was similar following exposure to $20 \mu \mathrm{g} / \mathrm{ml}$ Camalexin $(16.3 \pm 2.0$, a.u., $\mathrm{n}=10)$ and in the absence of Camalexin (15.3 \pm 1.6 , a.u., $\mathrm{n}=10)$. Thus, Camalexin did not appreciably induce oxidative stress (data not shown).

A further stimulator of eryptosis is ceramide. Ceramide abundance at the erythrocyte surface was thus quantified utilizing specific antibodies. As a result, the ceramide abundance was similar following exposure to $20 \mu \mathrm{g} / \mathrm{ml}$ Camalexin $(7.5 \pm 0.5$ a.u., $\mathrm{n}=10)$ and in the absence of Camalexin (7.1 \pm 0.8 a.u., $\mathrm{n}=10$ ). Thus, Camalexin did not appreciably induce ceramide abundance (data not shown). 
To explore, whether the effects of Camalexin involved kinase activity, the influence of Camalexin on annexin-V-binding and forward scatter was tested in the presence of protein kinase $\mathrm{C}$ inhibitors staurosporine $(1 \mu \mathrm{M})$ and chelerythrine $(10 \mu \mathrm{M})$, p38 kinase inhibitor SB $203580(2 \mu \mathrm{M})$ or casein kinase inhibitor D4476 $(10 \mu \mathrm{M})$. As illustrated in Fig. 5, the effect of Camalexin $(20 \mu \mathrm{g} / \mathrm{ml})$ on phosphatidylserine exposure was significantly blunted by staurosporine and chelerythrine. The percentage of annexin-V-binding erythrocytes following exposure to $20 \mu \mathrm{g} / \mathrm{ml}$ Camalexin was, however, similar in the absence of inhibitors (15.7 \pm 3.0 a.u., $\mathrm{n}=10)$ and in the presence of either SB203580 (11.3 \pm 6.8 a.u., $\mathrm{n}=10$, data not shown) or D4476 (12.4 \pm 4.5 a.u., $\mathrm{n}=10$, data not shown). Thus, the full effect of Camalexin required staurosporine and chelerythrine sensitive but not SB203580 sensitive or D4476 sensitive kinases.

In order to test for the involvement of caspases, the influence of Camalexin on annexinV-binding and forward scatter was tested in the presence of pancaspase inhibitor zVAD (10 $\mu \mathrm{M})$, of caspase-8 inhibitor zIETD-fmk $(50 \mu \mathrm{M})$, and of caspase-3 inhibitor zDEVD (50 $\mu \mathrm{M})$. As illustrated in Fig. 6, the effect of Camalexin $(20 \mu \mathrm{g} / \mathrm{ml})$ on phosphatidylserine exposure was significantly blunted by zVAD and zIETD-fmk. The percentage of annexin-V-binding erythrocytes following exposure to $20 \mu \mathrm{g} / \mathrm{ml}$ Camalexin was, however, similar in the absence of inhibitors (16.9 \pm 2.9 a.u., $n=8)$ and in the presence of zDEVD-fmk (19.1 \pm 1.9 a.u., $n=8$, data not shown).

\section{Discussion}

The present observations reveal a stimulating effect of Camalexin on suicidal erythrocyte death or eryptosis. Exposure of human erythrocytes to Camalexin is followed by cell shrinkage and cell membrane scrambling with phosphatidylserine translocation to the erythrocyte surface. In contrast, at the concentrations tested, Camalexin did not significantly modify hemolysis.

The effect of Camalexin on eryptosis was paralleled by an increase of cytosolic $\mathrm{Ca}^{2+}$ activity $\left(\left[\mathrm{Ca}^{2+}\right]_{\mathrm{i}}\right)$. Moreover, the effect of Camalexin on cell membrane scrambling was in large part dependent on $\mathrm{Ca}^{2+}$ entry from the extracellular space, as removal of extracellular $\mathrm{Ca}^{2+}$ significantly blunted the effect of Camalexin on phosphatidylserine translocation. $\mathrm{Ca}^{2+}$ entry from the extracellular space could further account for the Camalexin- induced cell shrinkage which could result from increase of $\left[\mathrm{Ca}^{2+}\right]_{i}$ with subsequent activation of $\mathrm{Ca}^{2+}$ sensitive $\mathrm{K}^{+}$ channels, $\mathrm{K}^{+}$exit, cell membrane hyperpolarization, $\mathrm{Cl}^{-}$exit and thus cellular loss of $\mathrm{KCl}$ with water.

The effect of Camalexin on phosphatidylserine translocation further apparently involves staurosporine and chelerythrine sensitive kinases such as protein kinase C. Accordingly, the effect of Camalexin on cell membrane scrambling was significantly blunted in the presence of protein kinase $\mathrm{C}$ inhibitor staurosporine, but not in the presence of $\mathrm{p} 38$ kinase inhibitor SB203580 and casein kinase inhibitor D4476. Camalexin-induced cell membrane scrambling was further significantly blunted in the presence of pan-caspase inhibitor zVAD and caspase 8 inhibitor zIETD-fmk, thus apparently involving activation of caspases. Increase of cytosolic $\mathrm{Ca}^{2+}$ concentration, activity of staurosporine and chelerythrine sensitive kinases as well as activated caspases are well known triggers of eryptosis [14]. Camalexin triggered cell membrane scrambling and cell shrinkage without enhancing the ceramide abundance. Moreover, Camalexin triggered eryptosis without inducing oxidative stress. Both, ceramide and oxidative stress are well known stimulators of eryptosis [14]

Consequences of eryptosis include rapid clearance of defective erythrocytes from circulating blood [14]. Failure of erythrocyte injury to trigger eryptosis may lead to hemolysis with release of hemoglobin, which passes the renal glomerular filter, precipitates in the acidic lumen of renal tubules, occludes nephrons and thus may lead to renal failure [72]. The rapid clearance of phosphatidylserine exposing erythrocytes from circulating blood could result in anemia as soon as the loss of erythrocytes surpasses the formation 
of new erythrocytes by erythropoiesis [14]. Phosphatidylserine exposing erythrocytes may further impair microcirculation [16, 73-77] due to adherence of eryptotic erythrocytes to the vascular wall [78], stimulation of blood clotting and triggering of thrombosis $[73,79,80]$,

To the extent that the effective concentrations are reached in plasma of Camalexin treated patients, side effects of the drug could include anemia and impaired microcirculation with increased risk of thrombosis.

In conclusion, Camalexin triggers eryptosis with cell shrinkage and cell membrane scrambling, an effect in large part dependent on $\mathrm{Ca}^{2+}$ entry, staurosporine sensitive kinases and zVAD-sensitive caspases.

\section{Acknowledgements}

The authors acknowledge the meticulous preparation of the manuscript by Tanja Loch. The study was supported by the Deutsche Forschungsgemeinschaft and Open Access Publishing Fund of Tuebingen University.

\section{Disclosure Statement}

The authors declare no conflict of interests.

\section{References}

1 Bednarek P: Sulfur-containing secondary metabolites from Arabidopsis thaliana and other Brassicaceae with function in plant immunity. Chembiochem 2012;13:1846-1859.

2 Glawischnig E: Camalexin. Phytochemistry 2007;68:401-406.

-3 Hansen BG, Halkier BA: New insight into the biosynthesis and regulation of indole compounds in Arabidopsis thaliana. Planta 2005;221:603-606.

4 Rauhut T, Glawischnig E: Evolution of camalexin and structurally related indolic compounds. Phytochemistry 2009;70:1638-1644.

5 Ahuja I, Kissen R, Bones AM: Phytoalexins in defense against pathogens. Trends Plant Sci 2012;17:73-90.

6 Ausubel FM, Katagiri F, Mindrinos M, Glazebrook J: Use of Arabidopsis thaliana defense-related mutants to dissect the plant response to pathogens. Proc Natl Acad Sci U S A 1995;92:4189-4196.

7 Hammerschmidt R, Dann EK: The role of phytoalexins in plant protection. Novartis Found Symp 1999;223:175-187; discussion 188-190.

-8 Ruszkowska J, Wrobel JT: Tryptophan-derived sulfur-containing phytoalexins--a general overview. Adv Exp Med Biol 2003;527:629-636.

9 Mezencev R, Mojzis J, Pilatova M, Kutschy P: Antiproliferative and cancer chemopreventive activity of phytoalexins: focus on indole phytoalexins from crucifers. Neoplasma 2003;50:239-245.

10 Mezencev R, Updegrove T, Kutschy P, Repovska M, McDonald JF: Camalexin induces apoptosis in T-leukemia Jurkat cells by increased concentration of reactive oxygen species and activation of caspase-8 and caspase-9. J Nat Med 2011;65:488-499.

11 Pilatova M, Ivanova L, Kutschy P, Varinska L, Saxunova L, Repovska M, Sarissky M, Seliga R, Mirossay L, Mojzis J: In vitro toxicity of camalexin derivatives in human cancer and non-cancer cells. Toxicol In Vitro 2013;27:939-944.

12 Smith B, Randle D, Mezencev R, Thomas L, Hinton C, Odero-Marah V: Camalexin-induced apoptosis in prostate cancer cells involves alterations of expression and activity of lysosomal protease cathepsin D. Molecules 2014;19:3988-4005.

13 Smith BA, Neal CL, Chetram M, Vo B, Mezencev R, Hinton C, Odero-Marah VA: The phytoalexin camalexin mediates cytotoxicity towards aggressive prostate cancer cells via reactive oxygen species. J Nat Med 2013;67:607-618. 


\section{Cellular Physiology Cell Physiol Biochem 2017;41:731-741

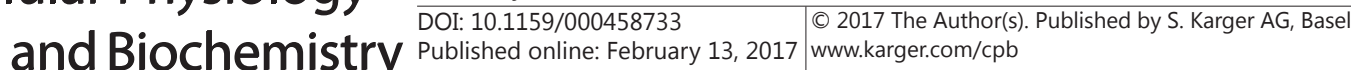

Almasry et al.: Camalexin-Induced Eryptosis

14 Lang E, Lang F: Mechanisms and pathophysiological significance of eryptosis, the suicidal erythrocyte death. Semin Cell Dev Biol 2015;39:35-42.

15 Lang PA, Kaiser S, Myssina S, Wieder T, Lang F, Huber SM: Role of Ca2+-activated K+ channels in human erythrocyte apoptosis. Am J Physiol Cell Physiol 2003;285:C1553-C1560.

-16 Abed M, Towhid ST, Mia S, Pakladok T, Alesutan I, Borst O, Gawaz M, Gulbins E, Lang F: Sphingomyelinaseinduced adhesion of eryptotic erythrocytes to endothelial cells. Am J Physiol Cell Physiol 2012;303:C991999.

17 Lau IP, Chen H, Wang J, Ong HC, Leung KC, Ho HP, Kong SK: In vitro effect of CTAB- and PEG-coated gold nanorods on the induction of eryptosis/erythroptosis in human erythrocytes. Nanotoxicology 2012;6:847856.

18 Maellaro E, Leoncini S, Moretti D, Del Bello B, Tanganelli I, De Felice C, Ciccoli L: Erythrocyte caspase-3 activation and oxidative imbalance in erythrocytes and in plasma of type 2 diabetic patients. Acta Diabetol 2013;50:489-495.

19 Bouguerra G, Aljanadi O, Bissinger R, Abbes S, Lang F: Embelin-Induced Phosphatidylserine Translocation in the Erythrocyte Cell Membrane. Cell Physiol Biochem 2015;37:1629-1640.

20 Officioso A, Alzoubi K, Manna C, Lang F: Clofazimine Induced Suicidal Death of Human Erythrocytes. Cell Physiol Biochem 2015;37:331-341.

21 Pagano M, Faggio C: The use of erythrocyte fragility to assess xenobiotic cytotoxicity. Cell Biochem Funct 2015;33:351-355.

-22 Peter T, Bissinger R, Enkel S, Alzoubi K, Oswald G, Lang F: Programmed erythrocyte death following in vitro Treosulfan treatment. Cell Physiol Biochem 2015;35:1372-1380.

-23 Stockinger K, Bissinger R, Bouguerra G, Abbes S, Lang F: Enhanced Eryptosis Following Exposure to Carnosic Acid. Cell Physiol Biochem 2015;37:1779-1791.

-24 Waibel S, Bissinger R, Bouguerra G, Abbes S, Lang F: Saquinavir Induced Suicidal Death of Human Erythrocytes. Cell Physiol Biochem 2015;37:1973-1982.

-25 Zierle J, Bissinger R, Egler J, Lang F: Lapatinib Induced Suicidal Death of Human Erythrocytes. Cell Physiol Biochem 2015;37:2275-2287.

26 Al Mamun Bhuyan A, Bissinger R, Cao H, Lang F: Triggering of Suicidal Erythrocyte Death by Bexarotene. Cell Physiol Biochem 2016;40:1239-1251.

-27 Al Mamun Bhuyan A, Bissinger R, Stockinger K, Lang F: Stimulation of Suicidal Erythrocyte Death by Tafenoquine. Cell Physiol Biochem 2016;39:2464-2476.

28 Al Mamun Bhuyan A, Signoretto E, Bissinger R, Lang F: Stimulation of Suicidal Erythrocyte Death by CeritinibTreatment of Human Erythrocytes. Cell Physiol Biochem 2016;40:1129-1140.

-29 Al Mamun Bhuyan A, Signoretto E, Bissinger R, Lang F: Enhanced Eryptosis Following Exposure to Dolutegravir. Cell Physiol Biochem 2016;39:639-650.

-30 Almasry M, Jemaa M, Mischitelli M, Faggio C, Lang F: Stimulation of Suicidal Erythrocyte Death by Phosphatase Inhibitor Calyculin A. Cell Physiol Biochem 2016;40:163-171.

-31 Bester J, Pretorius E: Effects of IL-1beta, IL-6 and IL-8 on erythrocytes, platelets and clot viscoelasticity. Sci Rep 2016;6:32188.

-32 Bissinger R, Bhuyan AA, Signoretto E, Lang F: Stimulating Effect of Elvitegravir on Suicidal Erythrocyte Death. Cell Physiol Biochem 2016;38:1111-1120.

33 Bissinger R, Malik A, Bouguerra G, Zhou Y, Singh Y, Abbes S, Lang F: Triggering of Suicidal Erythrocyte Death by the Antibiotic Ionophore Nigericin. Basic Clin Pharmacol Toxicol 2016;118:381-389.

-34 Egler J, Zierle J, Lang F: Stimulating Effect of Manumycin A on Suicidal Erythrocyte Death. Cell Physiol Biochem 2016;38:1147-1156.

-35 Fezai M, Slaymi C, Ben-Attia M, Lang F, Jemaa M: Purified Lesser weever fish venom (Trachinus vipera) induces eryptosis, apoptosis and cell cycle arrest. Sci Rep 2016;6:39288.

-36 Ghashghaeinia M, Giustarini D, Koralkova P, Koberle M, Alzoubi K, Bissinger R, Hosseinzadeh Z, Dreischer P, Bernhardt I, Lang F, Toulany M, Wieder T, Mojzikova R, Rossi R, Mrowietz U: Pharmacological targeting of glucose-6-phosphate dehydrogenase in human erythrocytes by Bay 11-7082, parthenolide and dimethyl fumarate. Sci Rep 2016;6:28754.

-37 Jemaa M, Mischitelli M, Fezai M, Almasry M, Faggio C, Lang F: Stimulation of Suicidal Erythrocyte Death by the CDC25 Inhibitor NSC-95397. Cell Physiol Biochem 2016;40:597-607. 


\section{Cellular Physiology Cell Physiol Biochem 2017;41:731-741

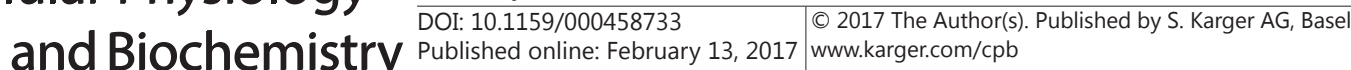 \\ Almasry et al.: Camalexin-Induced Eryptosis}

-38 Lang E, Pozdeev VI, Gatidis S, Qadri SM, Haussinger D, Kubitz R, Herebian D, Mayatepek E, Lang F, Lang KS, Lang PA: Bile Acid-Induced Suicidal Erythrocyte Death. Cell Physiol Biochem 2016;38:1500-1509.

-39 Macczak A, Cyrkler M, Bukowska B, Michalowicz J: Eryptosis-inducing activity of bisphenol A and its analogs in human red blood cells (in vitro study). Journal of Hazardous Materials 2016;307:328-335.

40 Mischitelli M, Jemaa M, Almasry M, Faggio C, Lang F: Stimulation of Erythrocyte Cell Membrane Scrambling by Quinine. Cell Physiol Biochem 2016;40:657-667.

41 Mischitelli M, Jemaa M, Almasry M, Faggio C, Lang F: Stimulation of Suicidal Erythrocyte Death by Rottlerin. Cell Physiol Biochem 2016;40:558-566.

42 Mischitelli M, Jemaa M, Almasry M, Faggio C, Lang F: Triggering of Erythrocyte Cell Membrane Scrambling by Emodin. Cell Physiol Biochem 2016;40:91-103.

43 Mischitelli M, Jemaa M, Almasry M, Faggio C, Lang F: Triggering of Suicidal Erythrocyte Death by Fascaplysin. Cell Physiol Biochem 2016;39:1638-1647.

44 Mischitelli M, Jemaa M, Almasry M, Faggio C, Lang F: Ca2+ Entry, Oxidative Stress, Ceramide and Suicidal Erythrocyte Death Following Diosgenin Treatment. Cell Physiol Biochem 2016;39:1626-1637.

45 Officioso A, Alzoubi K, Lang F, Manna C: Hydroxytyrosol inhibits phosphatidylserine exposure and suicidal death induced by mercury in human erythrocytes: Possible involvement of the glutathione pathway. Food and Chemical Toxicology 2016;89:47-53.

46 Officioso A, Manna C, Alzoubi K, Lang F: Bromfenvinphos induced suicidal death of human erythrocytes. Pestic Biochem Physiol 2016;126:58-63.

47 Peter T, Bissinger R, Lang F: Stimulation of Eryptosis by Caspofungin. Cell Physiol Biochem 2016;39:939949.

-48 Peter T, Bissinger R, Lang F: Erythrocyte Shrinkage and Cell Membrane Scrambling after Exposure to the Ionophore Nonactin. Basic Clin Pharmacol Toxicol 2016;118:107-112.

-49 Peter T, Bissinger R, Liu G, Lang F: Anidulafungin-Induced Suicidal Erythrocyte Death. Cell Physiol Biochem 2016;38:2272-2284.

-50 Peter T, Bissinger R, Signoretto E, Mack AF, Lang F: Micafungin-Induced Suicidal Erythrocyte Death. Cell Physiol Biochem 2016;39:584-595.

51 Bissinger R, Bouguerra G, Stockinger K, Abbes S, Lang F: Triggering of Suicidal Erythrocyte Death by Topotecan. Cell Physiol Biochem 2015;37:1607-1618.

52 Qadri SM, Chen D, Schubert P, Perruzza DL, Bhakta V, Devine DV, Sheffield WP: Pathogen inactivation by riboflavin and ultraviolet light illumination accelerates the red blood cell storage lesion and promotes eryptosis. Transfusion 2016;10.1111/trf.13959 [Epub ahead of print].

53 Qadri SM, Donkor DA, Bhakta V, Eltringham-Smith LJ, Dwivedi DJ, Moore JC, Pepler L, Ivetic N, Nazi I, FoxRobichaud AE, Liaw PC, Sheffield WP: Phosphatidylserine externalization and procoagulant activation of erythrocytes induced by Pseudomonas aeruginosa virulence factor pyocyanin. J Cell Mol Med 2016;20:710720 .

54 Signoretto E, Bissinger R, Castagna M, Lang F: Stimulation of Eryptosis by Combretastatin A4 Phosphate Disodium (CA4P). Cell Physiol Biochem 2016;38:969-981.

55 Signoretto E, Castagna M, Bhuyan AA, Lang F: Stimulating Effect of Terfenadine on Erythrocyte Cell Membrane Scrambling. Cell Physiol Biochem 2016;38:1425-1434.

56 Signoretto E, Castagna M, Lang F: Stimulation of Eryptosis, the Suicidal Erythrocyte Death by Piceatannol. Cell Physiol Biochem 2016;38:2300-2310.

57 Signoretto E, Honisch S, Briglia M, Faggio C, Castagna M, Lang F: Nocodazole Induced suicidal death of human erythrocytes. Cell Physiol Biochem 2016;38:379-392.

58 Signoretto E, Zierle J, Bhuyan AA, Castagna M, Lang F: Ceranib-2-induced suicidal erythrocyte death. Cell Biochem Funct 2016;34:359-366.

59 Signoretto E, Zierle J, Bissinger R, Castagna M, Bossi E, Lang F: Triggering of Suicidal Erythrocyte Death by Pazopanib. Cell Physiol Biochem 2016;38:926-938.

60 Waibel S, Bissinger R, Bouguerra G, Abbes S, Lang F: Ritonavir-Induced Suicidal Death of Human Erythrocytes. Basic Clin Pharmacol Toxicol 2016;119:51-57.

61 Lang E, Jilani K, Bissinger R, Rexhepaj R, Zelenak C, Lupescu A, Lang F, Qadri SM: Vitamin D-Rich Diet in Mice Modulates Erythrocyte Survival. Kidney Blood Press Res 2015;40:403-412.

62 Zierle J, Bissinger R, Bouguerra G, Abbes S, Lang F: Triggering of Suicidal Erythrocyte Death by Regorafenib. Cell Physiol Biochem 2016;38:160-172. 


\section{Cellular Physiology Cell Physiol Biochem 2017;41:731-741

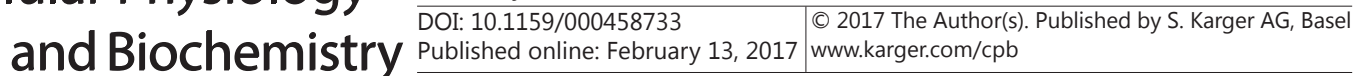 \\ Almasry et al.: Camalexin-Induced Eryptosis}

63 Al Mamun Bhuyan A, Signoretto E, Lang F: Triggering of Suicidal Erythrocyte Death by Psammaplin A. Cell Physiol Biochem 2016;39:908-918.

64 Alzoubi K, Egler J, Abed M, Lang F: Enhanced Eryptosis Following Auranofin Exposure. Cell Physiol Biochem 2015;37:1018-1028.

65 Bissinger R, Barking S, Alzoubi K, Liu G, Liu G, Lang F: Stimulation of Suicidal Erythrocyte Death by the Antimalarial Drug Mefloquine. Cell Physiol Biochem 2015;36:1395-1405.

-66 Abed M, Artunc F, Alzoubi K, Honisch S, Baumann D, Foller M, Lang F: Suicidal erythrocyte death in end-stage renal disease. J Mol Med (Berl) 2014;92:871-879.

-67 Polak-Jonkisz D, Purzyc L: Ca(2+) influx versus efflux during eryptosis in uremic erythrocytes. Blood Purif 2012;34:209-210; author reply 210.

68 Nicolay JP, Schneider J, Niemoeller OM, Artunc F, Portero-Otin M, Haik G, Jr., Thornalley PJ, Schleicher E, Wieder T, Lang F: Stimulation of suicidal erythrocyte death by methylglyoxal. Cell Physiol Biochem 2006;18:223-232.

69 Lang E, Gatidis S, Freise NF, Bock H, Kubitz R, Lauermann C, Orth HM, Klindt C, Schuier M, Keitel V, Reich M, Liu G, Schmidt S, Xu HC, Qadri SM, Herebian D, Pandyra AA, Mayatepek E, Gulbins E, Lang F, Haussinger D, Lang KS, Foller M, Lang PA: Conjugated bilirubin triggers anemia by inducing erythrocyte death. Hepatology 2015;61:275-284.

70 Kempe DS, Akel A, Lang PA, Hermle T, Biswas R, Muresanu J, Friedrich B, Dreischer P, Wolz C, Schumacher U, Peschel A, Gotz F, Doring G, Wieder T, Gulbins E, Lang F: Suicidal erythrocyte death in sepsis. J Mol Med (Berl) 2007;85:273-281.

71 Lang PA, Schenck M, Nicolay JP, Becker JU, Kempe DS, Lupescu A, Koka S, Eisele K, Klarl BA, Rubben H, Schmid KW, Mann K, Hildenbrand S, Hefter H, Huber SM, Wieder T, Erhardt A, Haussinger D, Gulbins E, Lang F: Liver cell death and anemia in Wilson disease involve acid sphingomyelinase and ceramide. Nat Med 2007;13:164170 .

72 Harrison HE, Bunting H, Ordway NK, Albrink WS: The Pathogenesis of the Renal Injury Produced in the Dog by Hemoglobin or Methemoglobin. J Exp Med 1947;86:339-356.

73 Andrews DA, Low PS: Role of red blood cells in thrombosis. Curr Opin Hematol 1999;6:76-82.

74 Closse C, Dachary-Prigent J, Boisseau MR: Phosphatidylserine-related adhesion of human erythrocytes to vascular endothelium. Br J Haematol 1999;107:300-302.

75 Gallagher PG, Chang SH, Rettig MP, Neely JE, Hillery CA, Smith BD, Low PS: Altered erythrocyte endothelial adherence and membrane phospholipid asymmetry in hereditary hydrocytosis. Blood 2003;101:4625-4627.

76 Pandolfi A, Di Pietro N, Sirolli V, Giardinelli A, Di Silvestre S, Amoroso L, Di Tomo P, Capani F, Consoli A, Bonomini M: Mechanisms of uremic erythrocyte-induced adhesion of human monocytes to cultured endothelial cells. J Cell Physiol 2007;213:699-709.

77 Wood BL, Gibson DF, Tait JF: Increased erythrocyte phosphatidylserine exposure in sickle cell disease: flowcytometric measurement and clinical associations. Blood 1996;88:1873-1880.

78 Borst O, Abed M, Alesutan I, Towhid ST, Qadri SM, Foller M, Gawaz M, Lang F: Dynamic adhesion of eryptotic erythrocytes to endothelial cells via CXCL16/SR-PSOX. Am J Physiol Cell Physiol 2012;302:C644-C651.

79 Chung SM, Bae ON, Lim KM, Noh JY, Lee MY, Jung YS, Chung JH: Lysophosphatidic acid induces thrombogenic activity through phosphatidylserine exposure and procoagulant microvesicle generation in human erythrocytes. Arterioscler Thromb Vasc Biol 2007;27:414-421.

-80 Zwaal RF, Comfurius P, Bevers EM: Surface exposure of phosphatidylserine in pathological cells. Cell Mol Life Sci 2005;62:971-988. 